\title{
ANTROPOLI HUKUM MENURUT PARA AHLI
}

\author{
Yori Septa Darmi \\ Mr.septadarmi.yori@gmail.com \\ No BP : 1710003600644 \\ UNIVERSITAS EKASAKTI
}

\section{A. Pendahuluan}

Antropologi secara etimologis berasal dari bahasa Yunani. Kata Anthropos berartimansia dan logos berarti ilmu pengetahuan. Jadi, antropologi adalah ilmu yang mempelajari manusia. Oleh

karena itu antropologi di dasarkan pada kemajuan yang telah dicapai ilmu pengetahuna sebelumnya. Pitirim Sorokim mengatakan bahwa Sosiologi adalah suatu ilmu yang mempelajari

hubungan dan pengaruh timbal balik antara aneka macam gejala-gejala sosial (gejala ekonomi dengan agama, keluarga dengan moral, hukum dengan ekonomi) dengan gejala lainnya (nonsosial). Berbeda dengan pendapat Rouceke dan Warren yang mengatakan bahwa Sosiologi adalah ilmu yang mempelajari hubungan manusia dengan kelompok-kelompok. Berdasarkan uraian di tersebut, maka Sosiologi adalah jelas merupakan ilmu sosial yang objeknya adalah masyarakat sebagai ilmu. Ia berdiri sendiri karena telah memiliki unsur ilmu pengetahuan. Dalam ilmu antropologi hukum dipelajari juga mengenai Peran, Status atau kedudukan, Nilai, Norma dan juga Budaya atau kebudayaan. Kesemuanya ini merupakan hal-hal yang sangat erat kaitannya dengan ilmu antropologi hukum. 


\section{B. Pembahasan}

Antropologi adalah ilmu tentang manusia. Antropologi berasal dari kata Yunani anthropos yang berarti manusia atau orang, dan logos yang berarti wacana (dalam pengertian bernalar, berakal atau secara etimologis antropologi berarti ilmu yang mempelajari manusia. Dalam melakukan kajian terhadap manusia, antropologi mengedepankan dua konsep penting yaitu: Holistik dan Komparatif. Karena itu kajian antropologi sangat memperhatikan aspek sejarah dan penjelasan menyeluruh untuk menggambarkan manusia melalui pengetahuan ilmu sosial ilmu hayati (alam), dan juga humaniora.

Antropologi bertujuan untuk lebih memahami dan mengapresiasi manusia sebagai entitas biologis homo sapiens dan makhluk sosial dalam kerangka kerja yang interdisipliner dan komprehensif. Oleh karena itu, antropologi menggunakan teori evolusi biologi dalam memberikan arti dan fakta sejarah dalam menjelaskan perjalanan umat manusia di bumi sejak awal kemunculannya. Antropologi juga menggunakan kajian lintas-budaya (Inggris cross-cultural) dalam menekankan dan menjelaskan perbedaan antara kelompok-kelompok manusia dalam perspektif material budaya, perilaku sosial, bahasa, dan pandangan hidup (worldview).

Dengan orientasinya yang holistik, antropologi dibagi menjadi empat cabang ilmu yang saling berkaitan, yaitu: Antropologi Biologi, Antropologi Sosial Budaya, Arkeologi, dan Linguistik. Keempat cabang tersebut memiliki kajian-kajian konsentrasi tersendiri dalam kekhususan akademik dan penelitian ilmiah, dengan topik yang unik dan metode penelitian yang berbeda-beda.

Antropologi lahir atau berawal dari ketertarikan orang-orang Eropa pada ciri-ciri fisik, adat istiadat, dan budaya etnis-etnis lain yang berbeda dari masyarakat yang dikenal di 
Eropa. Pada saat itu kajian antropologi lebih memusatkan pada penduduk yang merupakan masyarakat tunggal, tunggal dalam arti kesatuan masyarakat yang tinggal di suatu kawasan geografis yang sama, memiliki ciri fisik dan bahasa yang digunakan serupa, serta cara hidup yang sama. Namun demikian dalam perkembangannya, ilmu antropologi kemudian tidak lagi hanya mempelajari kelompok manusia tunggal yang mendiami suatu wilayah geografis yang sama. Kajian-kajian antropologi mengenai isuisu migrasi misalnya kemudian melahirkan penelitian-penelitian etnografis multi-situs. Hal ini terjadi karena dalam perkembangannya, pergerakan manusia baik dalam satu kawasan regional tertentu hingga dalam cakupan global adalah fenomena yang semakin umum terjadi.

a. Conrad Phillip Kottak Antropologi adalah ilmu yang mempelajari keragaman manusia secara holistik meliputi aspek sosial budaya, biologis, kebahasaan dan lingkungannya dalam dimensi waktu lampau, saat ini, dan di masa yang akan datang. Kottak membagi antropologi dalam empat subdisiplin, yaitu: antropologi sosial budaya, arkeologi, antropologi biologi dan linguistik antropologi.

b. David Hunter Antropologi adalah ilmu yang lahir dari keingintahuan yang tidak terbatas tentang umat manusia.

c. Koentjaraningrat Antropologi adalah ilmu yang mempelajari umat manusia pada umumnya dengan mempelajari aneka warna, bentuk fisik masyarakat serta kebudayaan yang dihasilkan.

d. William A. Haviland Antropologi adalah studi tentang umat manusia, berusaha menyusun generalisasi yang bermanfaat tentang manusia dan perilakunya serta untuk memperoleh pengertian yang lengkap tentang keanekaragaman manusia.

\section{Penutup}

Pendekatan holistik merupakan cabang pendekatan dari antropologi hukum yang melihat bagaimana skema kehidupan masyrakat di lihat secara menyeluruh dan juga komprehensif dalam kehidupan masyarakat Masyarakat merupakan suatu kesatuan masyarakat yang diikat oleh norma-norma hidup karena sejarah, tradisi maupun 
agama Menurut Karkono Kamajaya, budaya yaitu perwujudan budi manusia yang mencakup kemauan, cita-cita, ide dalam semangat untuk mencapai kesejahteraan, keselamatan, kebahagian lahir dan batin. Tiap kebudayaan yang hidup dalam suatu masyarakat bisa menampilkan suatu corak khas kebudayaan terutama terlihat oleh orang luar yang belum warga masyarakat yang bersangkutan. Corak khas dari suatu kebudayaan bisa tampil karena kebudayaan itu menghasilkan suatu unsur yang kecil berupa unsur kebudayaan fisik dengan bentuk yang khusus atau karena diantara pranata-pranatanya ada suatu pola sosial khusus sehingga berdasarkan atas corak khusus tadi maka suatu kebudayaan dapat dilihat dari kebudayaan lainnya dalam keberlangsungan budaya sebagai penentu nilai-nilai terbaik baik dari dalam maupun dari luar masyarakat. 